\title{
THE INTERNALIZATION OF SUNAN DRAJAT SOCIAL CONCEPT IN MULTICULTURAL EDUCATION IMPLEMENTATION
}

\author{
Ammar Zainuddin ${ }^{1}$, Juli Amaliya Nasucha ${ }^{2}$ \\ ammar.ikhac@gmail.com, amel.cemalcemil53@gmail.com \\ Institut Pesantren KH. Abdul Chalim
}

\begin{abstract}
Multicultural education is a manifestation of the process of respecting diversity among others and accepting each other. The most basic thing about this education is to uphold human values so as to create a sense of justice, togetherness and a sense of inequality or discrimination. As an example and role model that needs to be observed is Drajat's attitude in preaching and teaching morality. He and the community were known to be very wise and more concerned with caring for others. Thus it can be seen in his advice which includes catur menehono. It's a pity if Sunan's teachings on human rights are used as a memory in history. Therefore, here the writer wants to study more in the meaning of chess menehono teachings Sunan Drajat and try to redesign how the social teachings are applied in the scope of education.
\end{abstract}

Keywords: Sunan Drajat; catur menehono; multicultural education

\section{INTRODUCTION}

At the beginning of the new academic year 2017/2018 ago, the media had a chance shocked by the news of discrimination of the small people who want to register their students to school.

“Jakarta, CNN Indonesia - New Student Participants or PPDB 2017 is still colored by a number of issues. One of them What is concerning is that there are still public schools private sector that rejects poor students"(Rahman Indra, 2017).

It's not that the government is currently trying to marginalize "eradicate poverty". Not to mention our state precepts that have been conceptualized in independence with the sound of "just and civilized humanity". Even far away before that, the archipelago that was still royal was a Kanjeng Sunan in his da'wah he always strives to preserve the life of togetherness and mutual cooperation. But why is this the case, it still happens until now this and more unfortunate it turns out that this event took place inside an education. 
Sunan, what is meant by the writer here is Sunan Drajat. Long before the sunan has spread various noble teachings as the basis and harmonious community life guidelines. This is due to the wisdom he in understanding the culture of a weak society because it was deceived by the kingdom. This is where culture is between the people of the royal kingdom, abangan, and variety the gap wants to be erased by him with the spirit of togetherness and mutual cooperation.

The concept of Sunan Drajat is basically a principle that already exists in Islamic teachings. It's just that he tried to package the concept in the frame of the community's prosperity in the archipelago at that time. So that this concept should have been implemented even in the world of Islamic education in a more variant frame.

Therefore, the writer emphasizes more on the theme of education multicultural. Because the manifestation of the principle of multiculturalism can be reaching up to geographical differences, ethnicity, culture, language, religion, beliefs, mindset, and physical differences (diffable) or psychic (Murtadho, 2017). The hope is that this concept can be accepted and well implemented in all State and educational institutions Private, especially Islamic Education institutions or public schools participate in a society that is culturally diverse and religious.

With Catur Wenehono's internalization, as well as its development in multicultural education is expected to exist the benefits. The benefits of writing that researchers make include provide information about the teachings of Catur Wenehono Sunan Drajat. other than that as a reminder so that we as Indonesians do not forget noble teachings and values that have been initiated by our predecessors (read: The Wali Sanga).

According to Tilaar in (Sulton, 2015), Multicultural education is an approach to teaching and learning based on evaluating and democratic beliefs and seeing social diversity and world interdependence as part of cultural pluralism. Multicultural and education is a series of words that contain essence and consequences that cannot be separated. In multiculturalism, there is study material which is the basis for implementing education, both of which are equally important. In education, there are foundations and roots of culture which are extracted from the values of community culture. 
Multicultural education is as it is proposed by Gollnick and Chinn. That is the process of developing abilities for students to understand, acknowledge, respect and live while functioning comfortably and effectively in the face of all the different realities happened (Raihani, 2017). This is because multiculturalism contributes creating stereotypes of existing cultural forms (Irhandayaningsih, 2012).

Thus the author realizes that the social concept of Sunan Drajat has relevance to be applied in multicultural education. This is because according to according to Zamroni in Suryana, multicultural education is proposed to be used as an instrument of social engineering through education formal (Suryana \& Rusdiana, 2015).

The previous research conducted by (Martin, 2013) was the analysis of educative values the story of Sunan Drajat's Travel and its utilization as a storytelling source of learning materials for Grade VII Junior High School. Based on the results of research conducted by researchers obtained the following four conclusions, first, Sunan Drajat spread the teachings of Islam in the northern coastal region of Lamongan. The teachings delivered are mostly in the form of lectures and advice that are delivered gently and adapted to the social conditions of the local community. Second, religious educative values in the story of Sunan Drajat's journey, include religious educational values in the sector of syariat, religious educational values in the sector of tarikat, hakikat and ma'rifat. Third, social educative values in the story of Sunan Drajat's journey include: four wills (catur piwulang) and sapta paweling four wills of Sunan Drajat.

The writer wants to study more in the meaning of catur menehono teachings Sunan Drajat and try to redesign how the social teachings are applied in the scope of education. The results of this writing are expected to provide reflection about values that have been taught by Sunan Drajat during the spread of Islam and its contribution at this time. Next, we hope this writing can awaken the awareness of the archipelago to be able to apply the teachings of Drajat Sunan in the community, nation, and state as an effort realize the Republic of Indonesia which is rich in culture, customs, ethnicity and various religions.

\section{THE RESULT OF THE RESEARCH AND THE DISCUSSION}

To facilitate the reader in understanding this writing. Then in this discussion, the author first describes the social concept of Sunan degree and meaning. Furthermore, the 
interpretation and explanation of the concept of Sunan Drajat. At the end of the discussion, the author begins to integrate the concept of teaching into multicultural education and its application in the world of Islamic education.

\section{Da'wah Sunan Drajat Trip}

Among the famous Walisongo with the teachings of generosity and his social concern is Sunan Drajat. The most prominent thing in his preaching is his very serious concern on matters social. The Sunan always gives help to the general public, to support orphans and the poor as a social principle Islam is recommended. He first sought welfare his people, giving motivation to the community who then gave understanding and learning about Islamic teachings (Azzra, 1994).

He Sunan Drajat is the youngest son of Sunan Ampel and younger brother Sunan Bonang. He has nashab from Tyulen in Kazakhstan and Samarkand in Uzbekistan Central Asia which was then the grandfather of Ibrahim Asmarakandi migrate to Champa. His real name is Raden Qasim, called by Drajat because after he married the daughter of Sunan Gunung Jati in Cirebon. He lives in an area called Kadrajat so it is called Prince Kadrajat or Prince Drajat (Ibrahim, 2013).

Childhood until the age of adolescence he was in Surabaya together with his mother's father and received education about Islam from his own father. When viewed from the lineage, in Widji Saksono Sunan Drajat is Sunan Bonang's stepbrother the marriage of Sunan Ampel with Dyah Siti Manila the daughter of Arya Teja. So Sunan Bonang and Sunan Drajat are both sons of Sunan Ampel, it's just that they both have different mothers and both become members of Wali Songo in a spread Islamizing Java land (Nurhayati \& Dkk, 2007).

At one time, Kanjeng Sunan was given the task by his father, Sunan Ampel, to preach in the Paciran-Lamongan area of East Java. He departed and by sea by riding a boat belonging to the fishermen will go to sea. During the trip, he received an exam that was suddenly attacked by big waves, so that his boat hit the smell of the coral at once be broken and sink. Patiently and resignedly surrender his fate only to Allah, he still strives to try to swim while looking for a search, perhaps there is a place that can save him (Syamsuri, 1995). 
With earnest devotion to God, then came to him a group of Talang fish that came to approach Raden Qosim and he was pushed to the edge and finally, Raden Qasim could be saved from the threat of sea storms. Talang fish takes him to the beach Jelang village area which belongs to Banjarwati village, Paciran sub-district. Instantly Raden Qosim prostrated gratitude as proof of gratitude to Allah for protecting himself from danger.

Next, he performed the spiritual riadhah and uzlah at Ujung Pangkah for three months accompanied by not eating and not sleeping, he became famous karomah and followed by many followers. Then he was known as the spreader of Islam who has a high social spirit because he cares for welfare social society, especially the fate of the poor (Kusrahmadi, 2009). From this it can be concluded that his invitation emphasized a sense of togetherness and attention and instilled a sense of equality and unity.

Raden Qosim received the title Sunan Mayang Madu from Sunan Demak in 1520 AD. After Sunan Drajat develops da'wah Islam and led Dalem Duwur and his family for 36 years than died in $1522 \mathrm{AD}$ and was buried in the village of Drajad, subdistrict Paciran, Lamongan Regency, East Java (Ibrahim, 2013). Buried not far from his place of residence which is to the west of the mosque which he founded also.

In the course of da'wah, Sunan Drajat taught seven basic principles that the community known as Pepali pitu. These seven teachings have noble philosophical values. Because if it is examined more deeply, these seven teachings are Sunan Drajat efforts to summarize the Doctrine Islam simply as the main foundation in building community (See Atlas Walisongo, Agus Sunyoto).

\section{Scope of Teaching Catur Menehono}

To focus the discussion, the author here limits the study only discussing about and only at the last point of Pepali Pitu. Next the author termed this last principle as Catur Menehono. The word Catur means four and the meaning of Menehono giving, and the word menehono repeated four times as a closing and the last message from his teachings in preaching.

Following the teachings of catur menehono Sunan Drajat: First, Menehono teken marang wong kang wuto, meaning giving a stick to a blind person. Second, Menehono mangan marang wong kang luwe, that is to say, feed them hungry people. Third, 
Menehono busono marang wong kang kawuda, meaning, give clothes to people who don't have clothes. Fourth, Menehono Payung of marang wong kang kaudanan, meaning, give shelter to rainy people.

Menehono teken marang wong kang wuto, the author understands this advice in the case of education as one's duty to guide blind people to have a stick (knowledge). Those who are stupid sometimes do not know what is right and what is wrong. So it becomes an obligation to direct it to true knowledge.

Menehono mangan marang wong kang luwe, the author understands this advice in terms of education as a person's obligation to support the economic welfare of educators and guardians of hungry (poor) students. With their fulfillment of food (needs), the teaching and learning activities and the response back between educators and guardians are more harmonious and tolerant.

Menehono busana marang wong kang kawuda, the author understands this advice in terms of education as one's obligation to teach morals as a form of clothing. In covering up and decorating the moral generation of students who are naked (damaged and despicable).

Menehono pangiyup marang wong kang kaudanan, The author understands this advice in terms of education as the obligation of someone to provide an umbrella (feeling of security). To avoid and keep students away from rain (disturbance) which makes them not focus on learning. These disturbances are sometimes internal or internal.

\section{Multicultural Education and Sunan Drajat Thinking}

The concept of multiculturalism, not only the similarities between ethnic diversity concepts or ethnic cultures that characterize pluralistic societies but multiculturalism here emphasizes cultural diversity inequality. Multiculturalism reviews various problems that support the ideology of politics and democracy, justice and law enforcement, employment and business opportunities, human rights, the rights of community culture and minority groups, ethical and moral principles, level and quality of productivity, as well as various other concepts that are more relevant (Masamah \& Zamhari, 2016; Suryana \& Rusdiana, 2015; Tilaar, 2009). 
According to Choirul, multicultural education can be defined as education about cultural diversity in responding to demographic changes and environmental culture of certain communities or even the world as a whole or globally (Badrudin, 2015). Multicultural education was pioneered by James Banks, the emphasis and attention of Banks focused on his education. Banks believes that part of education is more directed at teaching how to think that what is thought. Because basically, the principles of multiculturalism are acknowledging and respecting diversity will greatly help to change the format of conducive and promising social behavior in the midst of a pluralistic society. Even in an Islamic view, actually multicultural education cannot be separated from the concept of pluralism (Syafe'i, 2018).

Multicultural education itself has four core values, namely appreciation of the reality of cultural diversity in society, recognition of human dignity and human rights, development of the responsibility of the world community, and the development of human responsibility towards the earth (Tilaar, 2009).

In the early days of students' lives, time was spent in their respective ethnic and cultural areas. These differences must be recognized in multicultural education, including among ethnic and racial minorities, groups of religious, religious, gender, economic conditions, regions/origins, physical and mental disabilities, age groups, and others (Suryana \& Rusdiana, 2015).

This factor causes the emergence of hostility between ethnic groups and groups. Therefore, through multicultural education from an early age, children are expected to be able to accept and understand cultural differences that affect differences usage (the way an individual behaves), folkways (habits that exist in society), mores (behavior in the community), and customs (customs of a community) (Adhani, 2014). Added again with the emergence of radicalism movement under the guise of Islam in various forms, like terrorism and domination the mainstream majority is really the real challenge to address the various differences that exist (Pageh \& Made, 2016).

The National Association for Multicultural Education, as stated by Azra, outlines three perspectives on multicultural education in his book. First, multicultural education as a philosophical concept based on the idea of independence, justice, equality, property rights, and human dignity. Second, multicultural education is a process that encompasses all aspects of school practice, policy, and organization as a 
tool to ensure the level of academic achievement of students. Third, multicultural education strengthens the belief that all learners, biographies, and experiences must be placed as centers in the teaching and learning process must be based on the context that is close (familiar) with students and shows various ways of thinking (Suryana \& Rusdiana, 2015).

Living in diversity and difference has become a sunnatullah for every servant of God. But with the differences that exist does not mean mutually demeaning and doing damage between human beings. Therefore, multicultural education becomes important to maintain stability among differences that arise between fellow social beings. That is the concept of the archipelago's insight, which is an effort to provide solutions in equating common views in realizing national integration in sovereign and national life (Rumi, 2014)

Likewise, with the preaching of Sunan Drajat, he always invites the community to work together and deny the existing social inequality. In the study of Walisongo Islamizing the land of Java, it was told that the social attitude of Sunan Drajat who was so socially deserved to be exemplified as a Muslim. Because in Islamic teachings there is a teaching of collectivism applied by him, namely the teachings of life help each other and live harmoniously in society. It is not life to be cruel and hostile, but to help one another in virtue and piety (QS.Al-Maidah: 2).

From the previous explanation, the concept of multicultural education and the concept of Islamic teachings applied by kanjeng Sunan have the same purpose and essence. That is a principled concept of education that teaches human equality and mutual respect in community life. Allah alone glorifies the descendants of the prophet Adam a.s. (QS. Al-Isra':70) and do not say "We have indeed glorified the heavens and the earth", then humans should have done prosperity on the face of the earth, sky, and mountains and looked after it (Ismail, 2001).

Therefore, it would be nice if the concept of Sunan Drajat especially the concept of "Catur Menehono" was integrated into multicultural education. as the goal of creating a society or young generation that is archipelago-minded and virtuous. Which can then be applied in all educational institutions in Indonesia especially in Islamic Education. Because the concept taught by Kanjeng Sunan also implied Islamic teachings. 


\section{Implementation of Catur Menehono}

Morals are behaviors that are inherent in someone whose behavior has been carried out repeatedly and continuously so that it becomes a habit and action that is done because the soul's drive is not outside compulsion. The goal of morality is to create humans as tall and perfect beings and to distinguish from other creatures. Morals want to make humans act well towards humans, fellow creatures and to God the God who created us.

The main purpose of the formation of noble character in Islam is that humans are in truth and always on the right path, the path that has been outlined by God. This is what will lead people to happiness in the world and in the hereafter. The formation of noble character in Islam is different from another moral coaching. Because the formation of noble character in Islam focuses more on tomorrow, which is the Day of Judgment and the things related to it, such as the calculation of charity, A person's morals will be considered noble if his actions reflect the values contained in the Qur'an and Sunnah.

Humans need to be educated or fostered to instill religious values in themselves. And when Allah created the human soul, with him Allah created the power of preparation to do good or evil. God also created humans capable of using members of the body he had given, without the provision of certain directions. God says in QS.AsySyams:7-8.

The explanation of the above verse shows that the creation of a perfect human being is upright in a righteous nature. God has also directed humans to abomination and piety, meaning that God explains the good and bad to humans. Thus, if a man in his behavior is good then the path of piety he has taken. Conversely, if the behavior is bad, then the abomination is what he has chosen.

Wenehono pangiyup marang wong kang kaudanan, The author understands this advice in terms of education as the obligation of someone to provide an umbrella (feeling of security). To avoid and keep students away from rain (disturbance) which makes them not focus on learning. These disturbances are sometimes internal or internal.

Therefore it would be nice if the concept of Sunan Drajat especially the concept of "Catur Menehono" was integrated into multicultural education. With the aim of 
creating a community or young generation with an archipelago perspective and virtuous. Which can then be applied in all educational institutions in Indonesia especially in Islamic Education. Because the concept taught by Kanjeng Sunan also implied Islamic teachings.

The effort to implement Sunan Drajat's thoughts on education, the author limits the teachers and students as people who are always involved in their daily processes of education. Then this implementation was only oriented to his seventh concept, namely the Catur Wenehono concept. Furthermore, the results of the analysis of the author in presenting the principles that should be applied in education by teachers and students.

First, the teacher's awareness in guiding his students. A teacher as an educator realizes that the knowledge he teaches in the future will have benefits and guide the success of his students. The teacher should not only transfer knowledge with the intention to abort the obligation as a teacher. It would be noble if a teacher really tried to continue teaching and be patient when facing students who lack response to the science that has been taught.

Besides that, the teacher must also know that every student is born from a different person and grows in different ways and attitudes. So here the teacher must be patient to guide his students in learning and always to pray for them to be given ease in accepting the knowledge they teach. Furthermore, recognizing that students are noble beings and only with the permission of His guidance in the form of knowledge can also be accepted by them.

Likewise with students towards their relatives in class and study. They should have the advantage (read: smart) not to elevate themselves and leave other relatives. As a good role model, it is advisable for the smart person to help his teacher by providing guidance and reviewing his learning relatives properly.

Secondly, the participation of teachers in providing the excess wealth they have to colleagues / other teachers who are still in need. Responsiveness and compassion towards others will establish a strong sense of brotherhood and a strong bond of love. With material assistance and tolerance, the welfare of each teacher will be a sense of togetherness and a gap between others.

With regard to students whose parents are less capable or living in a mediocre manner, the guardians of the students who are more educated must be involved. They 
made the school aware of the importance of mutual cooperation and caring for others. Furthermore, he advised those who were able to materially, to participate in financing the education of students who were not able/poor.

Third, the teacher's firmness to reprimand his students if ethics are not polite both verbal and action. Directing that the destruction of their civilization in the future is due to the destruction of their morals. Of course, the teacher's advice will also be acceptable if each teacher is well mannered so that he can be a simple role model and the closest to them when in school.

Furthermore, for students, it should have a firm attitude in reminding the ugliness of the behavior of their friends in socializing. Recalling the nobility of virtuous students will give a warning about the dangers of free association in the outside and wild world.

Fourth, teachers and students always maintain tolerance and foster a sense of concern for differences in togetherness. Help each other and complement each other. Realizing an atmosphere of learning and good friends and affection. As well as solving problems together until the creation of a safe, peaceful and peaceful learning environment and avoiding mini-conflicts between students and educators.

\section{CONCLUSIONS AND SUGGESTIONS}

In the implementation of multicultural education in Indonesia, there needs to be an effort to implement the social concept of Sunan Drajat which is always committed by him in preaching. The social concept referred to here is Catur Menehono. That is one of the concepts of the seven teachings that he always teaches his followers in preaching.

Efforts to realize this concept must have the participation of teachers and students in four main points. That is teacher awareness in guiding students, and students to their friends in achieving learning goals. The awareness of teachers and students in providing part of the assets to poor teachers and students. The awareness of teachers and students to teach morals and admonish the disgraceful. As well as the awareness of teachers and students to maintain tolerance and concern for others and complement each other.

Finally, the author chose the No-Frayed No Ivory phrase as the closing of this paper. The author realizes that this concept is very simple and the author's interpretation 
is very little and can even be refined. But what if there is simplicity but it cannot be applied easily. Therefore, the authors urge the readers to try it. Then discuss it further and develop it better. There is nothing else for the advancement of the generation of the nation's children in accordance with the purpose of sending them as Allah's Caliphs on the face of the Earth and Prosperity on His side. Amin... 


\section{REFERENCES}

Adhani, Y. (2014). Konsep Pendidikan Multikultural Sebagai Sarana Alternatif Pencegahan Konflik. Sosio Didaktika, 1(1).

Azzra, A. (1994). Ensiklopedi Islam. Jakarta: PT. Ichtiar Baru Van Hoeve.

Badrudin. (2015). Konsep Pendidikan Multikultural: Eksistensi dan Nilai-Nilai Urgensinya di Indonesia. Tazkiya, 16(2).

Ibrahim, R. (2013). Pendidikan Multikultural : Pengertian, Prinsip , dan Relevansinya Dengan Tujuan Pendidikan Islam. ADDIN, 7(1), 129-154.

Irhandayaningsih, A. (2012). Kajian Filosofis Terhadap Multikulturalisme Indonesia. HUMANIKA, 15(9), 1-8.

Ismail, F. (2001). Islam Transformasi Sosial dan Kontuinitas Sejarah. Yogyakarta: Tiara Wacana Yogya.

Kusrahmadi, S. D. (2009). Pentingnya Wawasan Nusantara dan Integrasi Nasional, 115.

Martin, R. (2013). Analisis Nilai Edukatif Kisah Perjalanan Sunan Drajat dan Pemanfaatannya sebagai Sumber Bahan Pembelajaran Bercerita untuk SMP kelas VII. Universitas Negeri Malang.

Masamah, U., \& Zamhari, M. (2016). Peran Guru Dalam Membangunan Pendidikan Berkesadaran Multikultural Di Indonesia. Quality, 4(2), 271-289.

Murtadho, A. (2017). Mengembangkan Pendidikan Multikultural Dalam Pembelajaran PAI. Al-Tadzkiyyah: Jurnal Pendidikan Islam, 7(1), 1-17.

Nurhayati, F., \& Dkk. (2007). Wali Songo: Profil dan Warisannya. Jakarta: Pustaka Timur.

Pageh, \& Made, I. (2016). Multikulturalisme dan Tantangannya di Indonesia: Jejak Kesetaraan Etnis Dan Kultur di Pura Republik/ Gambur Angalayang Kubutambahan Bali. SOSIO-DIDAKTIKA: Social Science Education Journal, 3(2), 115-125.

Rahman Indra. (2017). PPDB 2017, Masih Ada Siswa Miskin yang Ditolak Sekolah.

Raihani. (2017). Pendidikan Islam Dalam Masyarakat Multikultural. Yogyakarta: Pustaka Pelajar.

Rumi, J. (2014). Fihi Ma Fihi Mengarungi Samudera Kebijaksanaan. ('Isa 'Ali Al'Akub, Trans.). Yogyakarta: FORUM.

Sulton, A. (2015). Kurikulum Pesantren Multikultural: Nilai-Nilai Multikultural dalam Kurikulum Pondok Pesantren Sunan Drajat Banjarwati Paciran Lamongan. Ulul Albab, 16(1), 1-20.

Suryana, Y., \& Rusdiana, A. (2015). Pendidikan Multikultural: Suatu Upaya 
Penguatan Jati Diri Bangsa: Konsep-Prinsip-Implementasi. Bandung: Pustaka Setia.

Syafe'i, I. (2018). Model Kurikulum Pesantren Salafiyah Dalam Perspektif Multikultural. Al-Tadzkiyyah: Jurnal Pendidikan Islam, 8(2), 127-143.

Syamsuri, B. (1995). Kisah Wali Songo. Surabaya: Apollo.

Tilaar, H. A. . (2009). Kekuasaan dan Pendidikan: Manajemen Pendidikan Nasional dalam Pusaran Kekuasaan. Jakarta: Rineka Cipta. 